DOI 10.37882/2500-3682.2021.10.12

\title{
ФЕДЕРАЛЬНЫЕ НОРМАТИВНО-ПРАВОВЫЕ АКТЫ, ПОВЛИЯВШИЕ НА СОЦИАЛЬНУЮ СТРУКТУРУ ПОСТСОВЕТСКОГО ОБЩЕСТВА ЕВРАЗИЙСКОГО РЕГИОНА НА ПРИМЕРЕ РФ
}

\section{FEDERAL LAWS INFLUENCING ON SOCIAL STRUCTURE POST-SOVIET SOCIETY OF THE EURASIAN REGION BY THE EXAMPLE OF THE RUSSIAN FEDERATION}

\section{Kocharsky}

Summary: The presented article is devoted to study of federal laws as factor that influenced the social structure post-soviet society in Russia. The author attempts to research in works Russian leading researchers (M.K. Gorshkov, N.E. Tikhonova) impact of federal laws on social structure post-soviet society in Russia.

At this time taking into a account the relevance of research such social categories as: social stratification, social institutions and society, there is a need to study such an external factor as federal laws that influenced them.

In the research process the author points out that the external influence of federal laws on the social structure of post-Soviet society in the Russia is poorly studied by leading Russian sociologists.

The author concluded that federal laws are one of the factors that influenced the social structure of the Russian Federation in the post-Soviet period. This factor must be taken into account for the implementation of state policy in Russia.

Keywords: federal regulations, social structure, post-Soviet society, Eurasian region, RF.

\author{
Кочарский Лев Савельевич \\ аспирант, Сочинский государственный университет; \\ м.н.С., Институт пространственного развития \\ регионов, г. Сочи \\ lum.mas@yandex.ru
}

Аннотация: Представленная статья посвящена исследованию федеральных нормативно-правовых актов, как внешнего фактора повлиявшего на социальную структуру в современном российском обществе. Автором предпринята попытка, рассмотреть в трудах ведущих отечественных исследователей (М.К. Горшков, Н.Е. Тихонова) влияние федеральных нормативно-правовых актов на социальную структуру, в постсоветский период.

В работе отмечается, что в настоящее время, с учетом актуальности исследований, таких социальных категорий как: социальная стратификация, социальные институты и общество в целом существует необходимость исследования такого внешнего фактора, как федеральные нормативно-правовые акты, повлиявших на них.

В процессе исследования, автор указывает на то, что внешнее влияние федеральных нормативно-правовых актов, на социальную структуру постсоветского общества в РФ слабо изучено, ведущими отечественными социологами. Автор пришел к выводам, что федеральные нормативно-правовые акты, являются одним из факторов, повлиявшим на социальную структуру РФ в постсоветское время. Этот фактор необходимо учитывать, для реализации государственной политики в России.

Ключевые слова: федеральные нормативно-правовые акты, социальная структура, постсоветское общество, Евразийский регион, РФ.
B постсоветский период, является актуальным изучение социальных страт Евразийского региона, так как после распада СССР, политика либерализации привела к образованию новых суверенных государств и социальных институтов. Этот период характеризуется либерализацией внешней торговли, отказом от подготовки годовых планов экономического и социального развития и приватизацией советского имущества [1, с. 1-2]. Возникает зависимость экономики государства от международных экономических организаций таких как: МВФ, Всемирный банк, ВТО. В тоже время в евразийском регионе появляются такие межгосударственные организации как Евразийский экономический союз, ОБСЕ, СНГ, ШОС. Эти процессы привели к коренным изменениям в социальной структуре постсоветского общества на евразийском континенте. Исследование данных процессов привлекало внимание видных социологов, таки как: В.А. Ядов 1995, В.В. Радаеев 1997, Г.А. Ястребов, О.И. Шкаратан 2007; Н.Е. Тихонова 2017, М.К. Горшков, Ф.Э. Шереги 2021 и др.
Поэтому анализ причин, повлиявших на социальную структуру российского общества в постсоветское время, является актуальным. Еще одним аспектом подчеркивающим актуальность изучения социальной стратификации на евразийском континенте на примере РФ, являются идеи классических евразийцев. Несмотря на то, что большинство из их концепций были утопичны, следует отметить факторы (геополитические, территориальные и экономические), которые, по их мнению, влияли на все Российское общество и в том числе на его социальную структуру. Одной из причин, повлиявших на социальную структуру российского общества в постсоветское время, может выступать федеральное законодательство. Но в исследованиях ведущих отечественных социологов, практически не рассматривается данный фактор, либо, же он отражен слабо, что и обуславливает актуальность исследования. На основании этого целью статьи стало изучение влияния федеральных нормативно-правовых актов как внешнего фактора, влияющего на социальную 
структуру постсоветского общества евразийского региона на примере РФ.

Для исследования, были использованы следующие методы: синтеза, анализа и сравнительно-правовой метод. Сравнительно-правовой метод был применен для сравнения между собой федерального законодательства РФ и вычленения норм, повлиявших на социальную структуру.

Изучая различные подходы к определению феномена «социальная стратификация», необходимо указать на многоаспектность и сложноструктурированность данного общественного явления, выступающего в качестве динамично меняющейся системы исследования классового неравенства в обществе. При этом, анализируя сущностные аспекты социальной стратификации, следует отметить, что данный феномен имеет двойственную форму реализации: может рассматриваться как явление, так и как процесс.

Как явление оно представляет собой иерархически соподчиненное деление социума на социальные слои. Как процесс, социальная стратификация реализуется в качестве системы критериев и признаков оценки социального неравенства [2, с. 21]. В свою очередь, данная дефиниция, в сущности, является значимым социальным явлением в жизни общества.

Следует акцентировать внимание на том факте, что на социальную стратификацию, как на многогранное динамичное явление, в постсоветский период оказывали влияние не только внутренние, но и внешние факторы, в частности государственное управление. Государственная политика по формированию и упорядочиванию социальной структуры общества реализовывалась посредством нормотворчества. По мнению академика М.К. Горшкова «в настоящее время в России, произошли процессы сильно повлиявшие на развитие общества» [3, с. 15]. Соответственно, федеральные нормативные правовые акты как ключевой инструмент государственной политики могли выступать одним из факторов, на социальную структуру российского общества в последние 30 лет.

Со вступлением в законную силу Конституции 1993 г. были декларированы: равенство всех перед законом, включая отношение к религии (ст.19), свобода вероисповедания (ст.28), право на объединения (ст.30), право на частную собственность и занятие предпринимательской деятельности (ст.34,35.), право на свободный труд (ст.37) [5].

Так, ввиду декларирования свободной экономической деятельности, частной собственности и свободного распоряжения ею, формируется новый социальный слой
- предпринимателей. Положения статей 19, 28 основного закона, признающие идеологическое и мировоззренческое многообразие, закрепленные в основном законе, послужили законным основанием для образования социального слоя священнослужителей и религиозных деятелей, который в советское время не был легитимен в силу коммунистической идеологии атеизма. Нормы пунктов 4, 5 статьи 29 Конституции, декларирующие свободу поиска, получения, передачи, произведения и распространения информации любым законным способом, а также свободу массовой информации, в свою очередь, послужили основанием для образования социальных слоев, таких как блогеры и фрилансеры [5].

Законодательное закрепление права на «объединения, включая право создавать профессиональные союзы для защиты своих интересов», а также право на свободу деятельности общественных объединений способствовало формированию новых элементов в социальной структуре постсоветского общества таких как: общественные, религиозные и политические объединения, в том числе и иностранные, которые были законодательно закреплены в федеральных законах. В поправках к Конституции от 2020 года в статьях $(38,67)$, были прописаны такие элементы социальной структуры как: защитники отечества и дети.

Изучением социальной структуры постсоветского общества, занималась Н.Е. Тихонова. Она отмечает, что в эпоху Путинского правления, социальная структура подверглась сильным изменениям. Исследователь выделяет тенденцию повышения благосостояния граждан, с одной стороны, а с другой выделяя кредитную кабалу и исчезновения класса крестьян [6, с. 21-22]. На основании материального положения ученый выделяет 4 класса и 11 страт, сформировавшихся в постсоветский период. (Таб №1)

Н.Е. Тихонова, в своей работе «Негативная стабилизация» и факторы динамики благосостояния населения в посткризисной России», исследуя период 2014 - 2018 годов затрагивает экономические процессы, повлиявшие на социальную мобильность и структуру российского населения [6, с. 30-31].

Но необходимо отметить, что в данный период как раз вышел «Ф3 №422 «О проведении эксперимента по установлению специального налогового режима «налог на профессиональный доход». Данный закон, стал правовым основанием для появления новой социальной прослойки - самозанятых. Также, он повлиял на социальную мобильность, в частности способствуя переходу людей из медианного и нижнего среднего класса в социальный слой самозанятых. 
Таблица №1.

Численность основных классов и страт российского общества, выделенных по критерию уровня жизни, по состоянию на 2003, 2005 и 2006 гг., в \%

\begin{tabular}{|c|c|c|c|}
\hline Классы и стараты & 2003 г. & 2005 г. & 2006 г. \\
\hline Бедные & 32 & 34 & 34 \\
\hline Нищие (1 страта) & 6 & 7 & 7 \\
\hline Собственно бедные (2 страта) & 14 & 15 & 15 \\
\hline Пограничная 3 страта (нуждающиеся) & 12 & 12 & 12 \\
\hline $\begin{array}{l}\text { Медианный класс - малообеспеченные } \\
\text { (4 страта) }\end{array}$ & 28 & 28 & 26 \\
\hline Средние классы & 35 & 33 & 35 \\
\hline Нижний средний класс & 23 & 22 & 23 \\
\hline Нижний средний класс - 1 (5 страта) & 17 & 16 & 16 \\
\hline Нижний средний класс - 2 (6 страта) & 6 & 6 & 7 \\
\hline Средний класс & 12 & 11 & 12 \\
\hline Средний класс - 1 (7 страта) & 7 & 6 & 7 \\
\hline Средний класс - (8 страта) & 5 & 5 & 5 \\
\hline Богатые & 5 & 5 & 5 \\
\hline $\begin{array}{c}\text { Пограничная } 9 \text { страта (верхний } \\
\text { средний класс) }\end{array}$ & 4 & 4 & 4 \\
\hline Собственно богатые (10 страта) & 1 & 1 & 1 \\
\hline Элита и субэлита (11 страта) & - & - & - \\
\hline
\end{tabular}

Социолог справедливо отмечает, что в постсоветский период, произошло новое социальное образование прекариат, которое несет в себе черты протокласса [7; 286-287]. Этот протокласс, включает в себя людей занятый частичной или непостоянной трудовой деятельностью, а также работающие в теневом секторе экономики. В период 2014 - 2018 годов, произошло стремительное увеличение данного социального образования. В свою очередь, необходимо отметить, что в совместном исследовании Горшкова и Тихоновой, упоминается, что принятие новой редакции Ф3 №233 «О прожиточном минимуме в РФ» и постановление Правительства РФ № 56, повлияло на социальную мобильность и структуру общества в РФ [8, с. 156-158].

Исследователь А.А. Королев справедливо подчеркивает влияние на социальные слои новых евразийских межгосударственных организаций в евразийском регионе. Так «СНГ начального периода в основе своей представляет слабовыраженный межправительственный союз с неоднородным социально-экономическим комплексом с развивающимся национальным законодательством. Постепенно стало происходить развитие интеграции. Создание в 1996 г. Таможенного союза России, Белоруссии и Казахстана. Спустя три года подписание Договора между странами о едином экономическом пространстве. Учреждение союзного государства России и Белоруссии. Образование Евразийского экономического сообщества (ЕврАзЭС) по инициативе Н.А. Назарбаева. Все это стало платформой для новых интеграционных преобразований в евразийском континенте. Так В.В. Путин Н.А. Назарбаев и А.Г. Лукашенко подписали договор о создании Евразийского экономического союза» [10, с. 2-3]. Все это повлияло на социальную стратификацию евразийского региона.

Исходя из исследования, можно сделать вывод о том, что ведущие исследователи такие как М.К. Горшков и Н.Е. Тихонова в области социальной структуры общества, практически не придают значения федеральным нормативно-правовым актам евразийского региона на примере РФ, в качестве аспекта, влияющего на социальную структуру общества. На основании исследования мы пришли к выводу, что одним из факторов, который влияет на социальную структуру общества, являются федеральные нормативно-правовые акты. Этот фактор необходимо учитывать, для реализации государственной политики в России.

\section{ЛИТЕРАТУРА}

1. Кудряшова Е.В. Пробелы в правовом регулировании государственного планирования // Пробелы в российском законодательстве. Юридический журнал 2008 №3.

2. Социологический энциклопедический словарь (М., 1998).

3. Горшков М.К. Российское общество как новая социальная реальность // Россия реформирующаяся. Ежегодник / Отв. Ред. М.К. Горшков. - Вып.6. М.: Институт социологии РАН, 2007. С. 3-9

4. К Конституция Российской Федерации (принята всенародным голосованием 12.12.1993) (с учетом поправок, внесенных Законами РФ о поправках к Конституции РФ от 30.12.2008 N 6-ФКЗ, от 30.12.2008 N 7-ФК3, от 05.02.2014 N 2-ФК3, от 21.07.2014 N 11-ФКЗ) [Электронный ресурс] // Доступ из СПС «Консультант Плюс» (дата обращения: 09.06.2020).

5. Тихонова Н.Е. Динамика социально-экономического положения массовых слоёв населения России: 2003-2018 гг. // Социологическая наука и социальная практика. 2018. Том. 6. № 3. С. 7-25.

6. Тихонова Н.Е. «Негативная стабилизация» и факторы динамики благосостояния населения в посткризисной России // Социологический журнал. 2019. Том 25. № 1. С. 27-47.

7. Двадцать пять лет социальных трансформаций в оценках и суждениях россиян: опыт социологического анализа / [М.К. Горшков и др.]; отв. ред. М.К. Горшков, В.В. Петухов. — М.: Весь Мир, 2018. — 384 с. 
8. Тощенко Ж.Т. Прекариат - новый социальный класс // Социологические исследования. 2015. № 6. С. 3-13.

9. Средний класс в современной России / Отв. ред. М.К. Горшков, Н.Е. Тихонова; Ин-т социологии РАН. - М.: 2008. - 320 c.

10. Королев А.А. Евразийство: от идей к современной практике // Знание. Понимание. Умение 2015 №1.

\section{○ Кочарский Лев Савельевич (lum.mas@yandex.ru)}

Журнал «Современная наука: актуальные проблемы теории и практики»

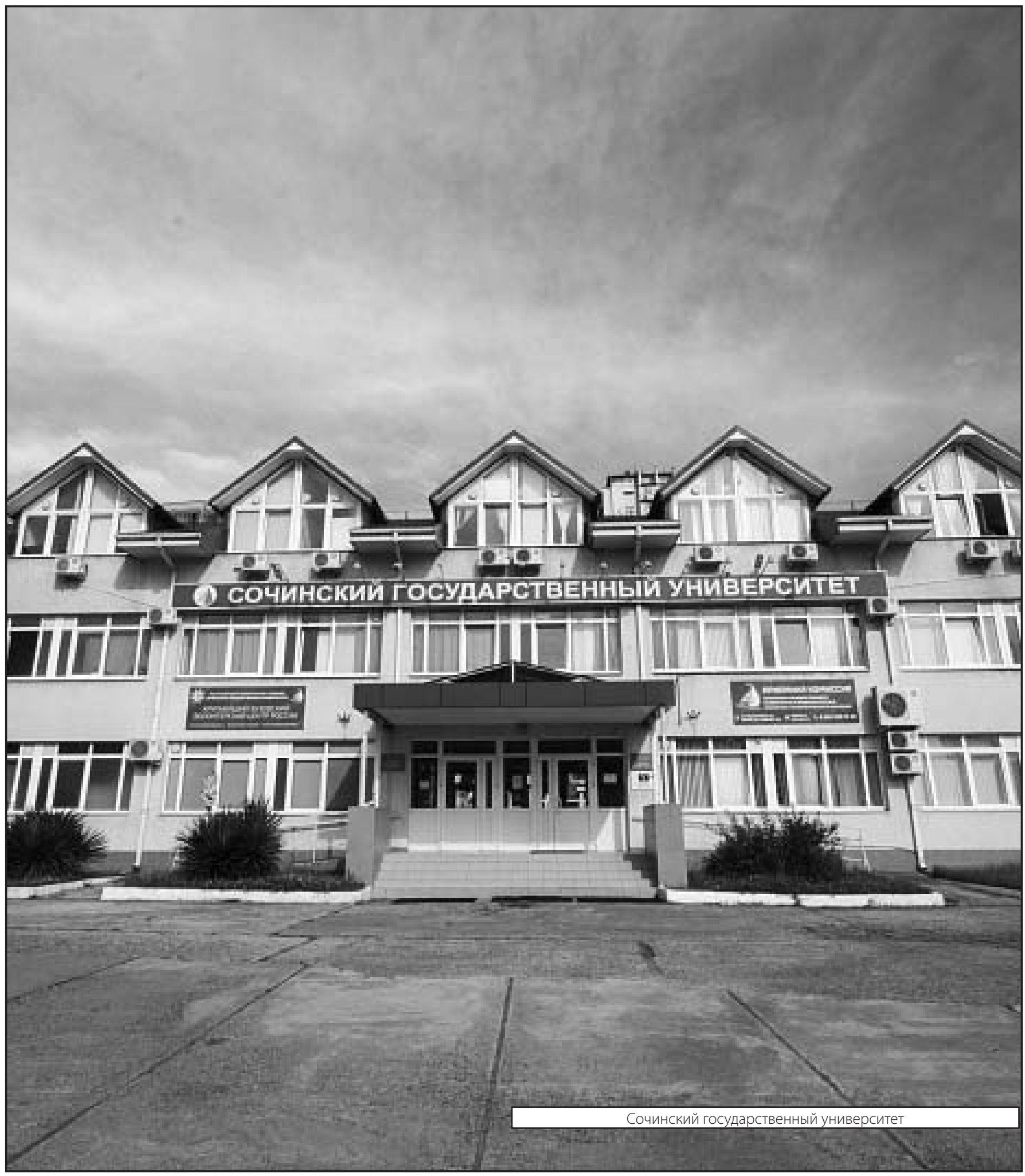

